\title{
MAIZE YIELD AND LEAF PHOTOSYNTHETIC CHARACTERISTICS IN RESPONSE TO PLANTING DENSITIES AND APPLICATION OF YUHUANGJIN, AS A NEW PLANT GROWTH REGULATOR
}

\author{
TonG, T. - GU, W. R. ${ }^{*}-$ LIU, X. M. - LI, C. F. \\ Department of Crop Cultivation and Farming System, College of Agriculture \\ Northeast Agricultural University, 150030 Harbin, PR China \\ ${ }^{*}$ Corresponding author \\ e-mail: wanronggu@163.com; phone: +86-451-5519-0472 \\ (Received 1t Mar 2019; accepted 21 ${ }^{\text {st }}$ May 2019)
}

\begin{abstract}
This study aims to analyze the effects of plant growth regulator on the chlorophyll fluorescence characteristics and yield of spring maize under different planting densities in Northeast China. 'Dongnong 253' was used as the material in this experiment and was planted at the densities of 5, 6, 7 and 8 plants $\mathrm{m}^{-2}$. The plants were sprayed at the jointing stage with the "Yuhuangjin" plant growth regulator. The results showed that increasing the planting density effectively increased the production of the maize populations, while it led to a decrease in the chlorophyll content, angle between the stem and leaf (ABSL) in the ear leaf, single plant dry weight and photosynthetic efficiency, as well as increases in the plant height, ear height and lodging risk. The application of "Yuhuangjin" decreased the plant height and ear height and increased the dry matter accumulation per plant and lodging resistance, increased the ABSL in the ear leaf, reduced the degree of overshadowing in the prophase, extended the duration of high leaf area index $(L A I)$, delayed the senescence process of the leaf and improved the canopy aeration and transmittance capability. The application of "Yuhuangjin" improved the photosynthetic capacities and maintained higher stable photosynthesis by significantly improving the chlorophyll fluorescence parameters, such as $F v / F m, Y(I I)$, and $q P$ and decreasing $Y(N O)$ and $q N$. This study showed that the highest yield was $11428.18 \mathrm{~kg} \mathrm{ha}^{-1}$ after the "Yuhuangjin" treatment at the planting density of 7 plants $\mathrm{m}^{-2}$. This experiment provided theoretical and experimental evidence for the effect of increased production from the use of plant growth regulator and high-density planting cultivation on spring maize in Northeast China.
\end{abstract}

Keywords: maize, high-density planting, chlorophyll fluorescence characteristics, photosynthesis rate, Yuhuangjin, yield

\section{Introduction}

Maize (Zea mays L.) plays an important role in ensuring world food security (Dong et al., 2013; Li et al., 2017). Increasing planting density is important to increase maize yields. The demand for maize is increasing with the rapidly increasing demands for food, livestock feed and bio-fuel at the global scale. Previous researchers have conducted extensive work in improving maize yield potentials and increasing yields per unit area (Diallo et al., 2015; Li et al., 2016; Biswas and Ma, 2017; Ren et al., 2017a). Previous studies have shown that increasing population density is an important method to achieve high yields (Rutger and Crowder, 1967; Roy et al., 2014). The analysis of 37 super-high-yield fields between 2006 and 2007 showed that the yields reached $15000 \mathrm{~kg} \mathrm{ha}^{-1}$ in the high yield field, the densities were in the range of 79725 84630 ears ha ${ }^{-1}$ (Chen et al., 2008). However, the current density of maize in the United States is generally 8 plants $\mathrm{m}^{-2}$ or higher. Dense planting is the main measure used to improve maize yields (Zhao et al., 2006; Benari and Makowski, 2016). The 
structure of the canopy group becomes poor with the increase in planting density, and increased density can cause the plants to shade each other. Increasing the planting density will also increase the competition for light, water and nutrients between plants (Kang et al., 2011; Farhad and Mehdi, 2015; Ren et al., 2017b). With the planting density increases, the individual plants in the group will shade each other, which will deteriorate the permeability of the canopy, decrease the photosynthetic performance, increase the plant height and increase the risk of lodging (Li et al., 2007; Sangakkara et al., 2012).

The maize in the area of Northeast China experiences low temperatures and rainy environments, which enable the root system to resist falling. Plant growth regulator is a synthetic substance that has the function of plant hormones (Yan et al., 2009). Plant growth regulator can effectively regulate the growth and development of plants and can effectively regulate the structural characteristics of the canopy. It is easy for the root system to fall in the later stages of growth and development, and this will cause many production cuts (Liao et al., 2014). Plant growth regulator technology can lower the height and ear height of maize plants (Meng et al., 2016). Plant growth regulators can enhance the anti-lodging ability, improve the chlorophyll content in leaves and prolong the duration of high leaf area index (LAI) values (Cheng and Liu, 2017). Plant growth regulator can truncate the elongation of internode cells, lower the center of the maize plant, increase the roughness of the stalks, improve the anti-lodging capacity (Fan et al., 2017), improve the leaf photosynthetic characteristics, photosynthetic efficiency and the rational distribution of assimilation products (Zhang et al., 2014). Moreover, plant growth regulator can also promote the absorption of the maize root system, promote the delivery of root secretions to the ground and promote the formation of grain yields (Cicchino et al., 2013).

Photosynthesis is the basis of plant growth and development (Inamoto et al., 2015). The photosynthetic rate is an important index that can reflect the photosynthetic capacity of a plant. The process of photosynthesis is composed of a series of complex photophysical and photochemical processes. During these processes, part of the light energy losses is released in the form of fluorescence. Chlorophyll fluorescence is closely related to photosynthesis (Hwang and Choo, 2016; Zhang et al., 2017).

"Yuhuangjin" plays an important role in the increase of maize planting in China. The plant growth regulator "Yuhuangjin" was provided by Fujian Haolun Biology Engineering Technology Co. Ltd, China. Its total effective component contents are the mixture of 3\% diethyl aminoethyl hexanoate and 27\% ethephon. Maize in Heilongjiang Province faces problems related to how both production and anti-lodging capacity can be synergistically increased. Previous researchers have conducted extensive work on the application of "Yuhuangjin", and it plays an important role in the mining potential of planting. In this experiment, we combined dense planting and plant growth regulator to study the photosynthetic characteristics of maize and the effects on yield. The results also provided an experimental basis for the reasonable application of "Yuhuangjin" in China.

\section{Materials and methods}

\section{Experimental materials and treatments}

The present experiment was carried out from 2013 to 2014 at the Xiang Fang experimental base, Northeast Agricultural University, Heilongjiang Province at $45^{\circ} 42^{\prime} \mathrm{N}$ 
latitude and $126^{\circ} 36^{\prime} \mathrm{E}$ longitude. The soil is a typical black soil (typic hapludoll in USDA soil taxonomy). The soil contained organic matter $\left(25.25 \mathrm{~g} \mathrm{~kg}^{-1}\right)$, total nitrogen (N) $\left(1.70 \mathrm{~g} \mathrm{~kg}^{-1}\right)$, available potassium (K) $\left(179.35 \mathrm{mg} \mathrm{kg}^{-1}\right)$, rapid available phosphorus (P) $\left(65.34 \mathrm{mg} \mathrm{kg}^{-1}\right)$, and alkali hydrolysable nitrogen $(\mathrm{N})\left(118.21 \mathrm{mg} \mathrm{kg}^{-1}\right)$. The climate in the region is temperate continental monsoon. The weather data from 2013 and 2014 are provided in Table 1.

Table 1. Daily mean values of the weather variables at the experimental site during the six months of the maize growing season in 2013 and 2014

\begin{tabular}{c|cc|cc|cc}
\hline \multirow{2}{*}{ Month } & \multicolumn{2}{|c|}{$\begin{array}{c}\text { Average temperature } \\
\left({ }^{\circ} \mathbf{C}\right)\end{array}$} & \multicolumn{2}{c|}{$\begin{array}{c}\text { Precipitation } \\
(\mathbf{m m})\end{array}$} & \multicolumn{2}{c}{$\begin{array}{c}\text { Sunshine hours } \\
(\mathbf{h})\end{array}$} \\
\cline { 2 - 7 } & $\mathbf{2 0 1 3}$ & $\mathbf{2 0 1 4}$ & $\mathbf{2 0 1 3}$ & $\mathbf{2 0 1 4}$ & $\mathbf{2 0 1 3}$ & $\mathbf{2 0 1 4}$ \\
\hline April & 4.4 & 10.3 & 10.8 & 6.1 & 202.3 & 267.0 \\
May & 17.9 & 14.3 & 73.5 & 91.4 & 240.7 & 127.5 \\
June & 21.4 & 22.9 & 86.4 & 56.8 & 151.7 & 216.8 \\
July & 23.9 & 23.1 & 198.0 & 115.5 & 195.1 & 159.9 \\
August & 22.5 & 21.9 & 125.7 & 83.8 & 163.7 & 208.1 \\
September & 15.8 & 15.5 & 31.5 & 32.2 & 230.1 & 184.4 \\
Total $^{\text {a }}$ & 17.7 & 18 & 525.9 & 385.8 & 1183.6 & 1163.7 \\
\hline
\end{tabular}

${ }^{a}$ Precipitation and sunshine are monthly sums, while temperature is a monthly mean of daily means

Maize was hand-sown at $7 \mathrm{~cm}$ depth and $70 \mathrm{~cm}$ row distance on May 1 in 2013 and May 1 in 2014 in a plot size of $84 \mathrm{~m}^{2}$. The supply trial variety was 'Dongnong 253'. The tested planting densities were 5 plants $\mathrm{m}^{-2}, 6$ plants $\mathrm{m}^{-2}, 7$ plants $\mathrm{m}^{-2}$ and 8 plants $\mathrm{m}^{-2}$. Using the same density of rope, $20 \mathrm{ml}$ of "Yuhuangjin" was added to $30 \mathrm{~kg}$ of water. The solution was sprayed on six leaves and one bud, and water was used as a control. Diammonium phosphate $(250 \mathrm{~kg})$, urea $(75 \mathrm{~kg})$, and potassium sulfate $(150 \mathrm{~kg})$ were used as seed fertilizer, and nitrogen fertilizer was applied per hectare during the jointing stage.

\section{Measurement of leaf area index (LAI)}

The leaf area was measured using three randomly selected maize plants in each plot at the silking stage. The length and maximum width of each leaf were measured with a ruler. Leaf area index $(L A I)=$ single plant leaf area $\times$ the number of plants per unit of land $\div$ unit land area.

\section{Measurement of chlorophyll content (SPAD)}

The CCM-200+ (Beijing Aozuo Ecology Instrument Co, Ltd) chlorophyll meter was used to measure the relative chlorophyll content in leaves. In each treatment phase, three plants with uniform leaf ages were selected and marked. The determination time was between 8:30 and 10:00 am, and the ear-leaf content of each reproductive period was measured. The leaf tip, leaf center and leaf base of the leaves were determined, and the mean values were calculated as the determination value of the blade. The three measured values of each treatment were calculated, and the average value was taken as the $S P A D$ value of the treatment. In the subsequent measurements, the marked plants were selected for measurement. 


\section{Measurement of net photosynthetic rate of leaves (Pn)}

The net photosynthetic rate of the leaves was determined between 9:00 and 11:00 am, and a hand-held photosynthetic rate meter instrument CI-340 (Zealquest Scientific Technology Co., Ltd.) was used to measure the ear-leaf content. The mean value of the three measured values was used as the measured value for the treatment.

\section{Measurement of chlorophyll fluorescence parameters}

The middle of the selected plant was measured to determine the chlorophyll fluorescence parameters, and the measurement was collected between 8:30 and 10:00 am. First, a leaf clip was used to hold the middle of the ear leaf, and the ear leaf was kept in the dark treatment for 20 minutes; then, the leaf clip operation steps were followed. The mean value of the three measurements was taken as the measured value. The PSII maximum quantum yield $(F v / F m)$, actual quantum yield $(Y(I I))$, nonregulating performance dissipation quantum yield $(Y(N O))$, non-photochemical quenching parameters $(q N)$, and photochemical quenching parameters $(q P)$ were calculated. The measurement instrument was a portable modulated chlorophyll fluorometer (PAM-2500) (KANGGAOTE Science and Technology Co., Ltd).

\section{Measurement of biomass and yield}

To determine the biomass and yield, two consecutive four-meter lengths were selected for each process. The rows per ear, number of ear, kernels row, number of row and hundred grain weight were calculated. After harvest, 20 ears were selected to calculate the kernels row, number of row, hundred grain weight, and the theoretical yield. The biomass was determined by the drying method, and the stalks and grains were dried separately. Each process was repeated three times, and the results were averaged.

\section{Statistical analyses}

According to the analysis of variance principles, data were statistically analyzed following standard statistical methods using Microsoft Excel 2010 and SPSS 12.0. Differences between treatments were determined by a posteriori Tukey's test at a significance level of 0.05 .

\section{Results}

\section{Effects of plant growth regulator on leaf area index of spring maize in different planting densities}

During the reproductive process, the $L A I$ first showed an increasing then a decreasing trend in both treatments (Table 2). The LAI peaks appeared around the time of silking, and the $L A I$ also increased with the increase in planting density. In the "Yuhuangjin" treatment, the peak $L A I$ values were $0.89 \%\left(5\right.$ plants $\left.\mathrm{m}^{-2}\right), 3.95 \%\left(6\right.$ plants $\left.\mathrm{m}^{-2}\right), 1.23 \%$ (7 plants $\mathrm{m}^{-2}$ ) and $8.74 \%\left(8\right.$ plants $\mathrm{m}^{-2}$ ) lower than the peak $L A I$ values in the water treatment. From the silking stage to the dough stage, the $L A I$ values were $3.75 \%$ $\left(5\right.$ plants $\left.\mathrm{m}^{-2}\right), 6.47 \%\left(6\right.$ plants $\left.\mathrm{m}^{-2}\right), 7.14 \%\left(7\right.$ plants $\left.\mathrm{m}^{-2}\right)$ and $14.60 \%\left(8\right.$ plants $\left.\mathrm{m}^{-2}\right)$ lower than the peak values in the water treatment. 


\section{Effects of plant growth regulator on chlorophyll SPAD in the leaves of northeast spring maize under different planting densities}

From the silking stage to the dough stage, the chlorophyll $S P A D$ value decreased in the two treatments (Table 3). In the water treatment, the SPAD value decreased in every growth period with the increase in density. From the silking stage to the dough stage, the SPAD value declined by $16.72 \%\left(5\right.$ plants $\left.\mathrm{m}^{-2}\right), 23.52 \%\left(6\right.$ plants $\left.\mathrm{m}^{-2}\right), 25.01 \%$ $\left(7\right.$ plants $\mathrm{m}^{-2}$ ) and $25.73 \%\left(8\right.$ plants $\left.\mathrm{m}^{-2}\right)$.

Table 2. The effects of plant growth regulator on the LAI of spring maize under different planting densities in Northeast China

\begin{tabular}{|c|c|c|c|c|c|c|}
\hline Treatment & $\begin{array}{c}\text { Density } \\
\left(\text { plants } \mathbf{m}^{-2}\right)\end{array}$ & $\begin{array}{c}\text { Jointing } \\
\text { stage }\end{array}$ & $\begin{array}{c}\text { Trumpet } \\
\text { stage }\end{array}$ & Silking & $\begin{array}{c}\text { Grain filling } \\
\text { stage }\end{array}$ & $\begin{array}{c}\text { Dough } \\
\text { stage }\end{array}$ \\
\hline \multirow{4}{*}{ Water } & 5 & $2.25 \pm 0.12^{\mathrm{ab}}$ & $3.55 \pm 0.06^{\mathrm{d}}$ & $4.05 \pm 0.09^{d}$ & $3.79 \pm 0.07^{\mathrm{d}}$ & $3.28 \pm 0.07^{\mathrm{f}}$ \\
\hline & 6 & $2.46 \pm 0.62^{\mathrm{ab}}$ & $4.13 \pm 0.12^{\mathrm{c}}$ & $4.39 \pm 0.13^{\mathrm{cd}}$ & $4.06 \pm 0.05^{\mathrm{c}}$ & $3.45 \pm 0.05^{\mathrm{ef}}$ \\
\hline & 7 & $2.58 \pm 0.03^{\mathrm{ab}}$ & $4.73 \pm 0.16^{b}$ & $4.89 \pm 0.07^{b}$ & $4.49 \pm 0.12^{\mathrm{b}}$ & $3.72 \pm 0.08^{\mathrm{cd}}$ \\
\hline & 8 & $2.88 \pm 0.09^{\mathrm{a}}$ & $5.22 \pm 0.06^{\mathrm{a}}$ & $5.59 \pm 0.08^{\mathrm{a}}$ & $4.71 \pm 0.05^{\mathrm{a}}$ & $3.84 \pm 0.06^{\mathrm{c}}$ \\
\hline \multirow{4}{*}{$\begin{array}{l}\text { Plant growth } \\
\text { regulator }\end{array}$} & 5 & $2.12 \pm 0.12^{\mathrm{b}}$ & $3.52 \pm 0.03^{\mathrm{d}}$ & $4.02 \pm 0.05^{\mathrm{d}}$ & $3.84 \pm 0.13^{\mathrm{d}}$ & $3.40 \pm 0.10^{\text {ef }}$ \\
\hline & 6 & $2.36 \pm 0.45^{\mathrm{ab}}$ & $4.11 \pm 0.22^{\mathrm{c}}$ & $4.22 \pm 0.23^{\mathrm{d}}$ & $4.16 \pm 0.07^{c}$ & $3.58 \pm 0.12^{\mathrm{de}}$ \\
\hline & 7 & $2.53 \pm 0.48^{\mathrm{ab}}$ & $4.71 \pm 0.29^{b}$ & $4.83 \pm 0.48^{\mathrm{bc}}$ & $4.52 \pm 0.06^{\mathrm{b}}$ & $4.02 \pm 0.17^{\mathrm{b}}$ \\
\hline & 8 & $2.67 \pm 0.12^{\mathrm{ab}}$ & $4.68 \pm 0.23^{b}$ & $5.10 \pm 0.50^{\mathrm{b}}$ & $4.72 \pm 0.15^{\mathrm{a}}$ & $4.25 \pm 0.14^{\mathrm{a}}$ \\
\hline
\end{tabular}

The values represent the mean \pm SE $(n=7)$. The values with the same letters in the columns are not significantly different at $\mathrm{P}<0.05$

Table 3. The effects of plant growth regulator on the chlorophyll SPAD values of spring maize under different planting densities in Northeast China

\begin{tabular}{c|c|c|c|c}
\hline Treatment & $\begin{array}{c}\text { Density } \\
\left(\text { plants m}^{-2}\right)\end{array}$ & Silking & Grain filling stage & Dough stage \\
\hline \multirow{3}{*}{ Water } & 5 & $77.14 \pm 4.52^{\mathrm{ab}}$ & $74.50 \pm 4.03^{\mathrm{a}}$ & $64.24 \pm 9.82^{\mathrm{a}}$ \\
& 6 & $68.53 \pm 2.37^{\mathrm{bcd}}$ & $59.09 \pm 4.52^{\mathrm{b}}$ & $52.41 \pm 3.97^{\mathrm{bc}}$ \\
& 7 & $63.58 \pm 6.98^{\mathrm{cd}}$ & $59.18 \pm 3.49^{\mathrm{b}}$ & $47.68 \pm 3.66^{\mathrm{c}}$ \\
& 8 & $61.27 \pm 6.16^{\mathrm{d}}$ & $53.01 \pm 2.62^{\mathrm{c}}$ & $45.50 \pm 8.98^{\mathrm{c}}$ \\
\hline \multirow{3}{*}{ Plant growth } & 5 & $82.66 \pm 9.52^{\mathrm{a}}$ & $71.17 \pm 1.78^{\mathrm{a}}$ & $65.34 \pm 2.09^{\mathrm{a}}$ \\
regulator & 6 & $74.83 \pm 4.70^{\mathrm{abc}}$ & $63.60 \pm 1.95^{\mathrm{b}}$ & $62.46 \pm 1.19^{\mathrm{ab}}$ \\
& 7 & $68.57 \pm 6.24^{\mathrm{bcd}}$ & $65.24 \pm 4.62^{\mathrm{b}}$ & $60.13 \pm 3.95^{\mathrm{ab}}$ \\
\hline
\end{tabular}

In the "Yuhuangjin" treatment, the SPAD value was higher than that in the water treatment in every growth period. The SPAD value in the "Yuhuangjin" treatment was higher than that in the water treatment by $7.14 \%\left(5\right.$ plants $\left.\mathrm{m}^{-2}\right), 9.19 \%\left(6\right.$ plants $\left.\mathrm{m}^{-2}\right)$, $7.85 \%\left(7\right.$ plants $\left.\mathrm{m}^{-2}\right)$ and $8.77 \%\left(8\right.$ plants $\left.\mathrm{m}^{-2}\right)$ at the silking stage. From the silking stage to the dough stage, SPAD value declined by $18.52 \%$ (5 plants $\mathrm{m}^{-2}$ ), 16.54\% (6 plants $\left.\mathrm{m}^{-2}\right), 12.30 \%\left(7\right.$ plants $\left.\mathrm{m}^{-2}\right)$ and $16.71 \%\left(8\right.$ plants $\left.\mathrm{m}^{-2}\right)$ in the "Yuhuangjin" treatment. Except for the 5 plants $\mathrm{m}^{-2}$ density, the "Yuhuangjin" treatment decreased the chlorophyll degradation rate at varying degrees in the later stages of procreation. 


\section{Effects of plant growth regulator on the net photosynthetic rate (Pn) of leaves of northeast spring maize under different planting densities}

From the silking stage to the dough stage, the net photosynthetic rate of the leaves decreased gradually in both treatments (Table 4). In the water treatment, the net photosynthetic rate was $43.29 \mu \mathrm{mol} \mathrm{m} \mathrm{m}^{-2} \mathrm{~s}^{-1}\left(5\right.$ plants $\left.\mathrm{m}^{-2}\right), 40.42 \mu \mathrm{mol} \mathrm{m} \mathrm{m}^{-2} \mathrm{~s}^{-1}$ $\left(6\right.$ plants $\left.\mathrm{m}^{-2}\right), 38.79 \mu \mathrm{mol} \mathrm{m}^{-2} \mathrm{~s}^{-1}\left(7\right.$ plants $\left.\mathrm{m}^{-2}\right)$ and $37.59 \mu \mathrm{mol} \mathrm{m}^{-2} \mathrm{~s}^{-1}\left(8\right.$ plants $\left.\mathrm{m}^{-2}\right)$ at the silking stage. When the planting density increased, the net photosynthetic rate decreased. Compared to the 5 plants $\mathrm{m}^{-2}$ density, the net photosynthetic rate in the other densities reduced by $6.64 \%\left(6\right.$ plants $\left.\mathrm{m}^{-2}\right), 10.40 \%\left(7\right.$ plants $\left.\mathrm{m}^{-2}\right)$ and $13.17 \%(8$ plants $\mathrm{m}^{-2}$ ). At various densities, the net photosynthetic rate decreased by $46.23 \%$ (5 plants $\left.\mathrm{m}^{-2}\right), 44.47 \%\left(6\right.$ plants $\left.\mathrm{m}^{-2}\right), 44.72 \%\left(7\right.$ plants $\left.\mathrm{m}^{-2}\right)$ and $49.70 \%\left(8\right.$ plants $\left.\mathrm{m}^{-2}\right)$ from the silking stage to the dough stage.

Table 4. The effects of plant growth regulator on the Pn of spring maize leaves under different planting densities in Northeast China

\begin{tabular}{c|c|c|c|c|c|c}
\hline Treatment & $\begin{array}{c}\text { Density } \\
\text { plants }^{-2} \text { ) }\end{array}$ & $\begin{array}{c}\text { Jointing } \\
\text { stage }\end{array}$ & $\begin{array}{c}\text { Trumpet } \\
\text { stage }\end{array}$ & Silking & $\begin{array}{c}\text { Grain filling } \\
\text { stage }\end{array}$ & $\begin{array}{c}\text { Dough } \\
\text { stage }\end{array}$ \\
\hline \multirow{3}{*}{ Water } & 5 & $15.93 \pm 0.09^{\mathrm{b}}$ & $29.40 \pm 1.80^{\mathrm{b}}$ & $43.29 \pm 1.31^{\mathrm{bc}}$ & $35.05 \pm 0.88^{\mathrm{b}}$ & $23.28 \pm 0.88^{\mathrm{cd}}$ \\
& 6 & $14.50 \pm 0.16^{\mathrm{d}}$ & $26.53 \pm 0.91^{\mathrm{de}}$ & $40.42 \pm 0.32^{\mathrm{d}}$ & $32.22 \pm 0.42^{\mathrm{e}}$ & $22.44 \pm 0.43^{\mathrm{de}}$ \\
& 7 & $13.97 \pm 0.07^{\mathrm{e}}$ & $25.23 \pm 0.17^{\mathrm{ef}}$ & $38.79 \pm 0.41^{\mathrm{ef}}$ & $31.02 \pm 0.18^{\mathrm{f}}$ & $21.44 \pm 0.17^{\mathrm{e}}$ \\
& 8 & $13.61 \pm 0.22^{\mathrm{e}}$ & $24.58 \pm 0.44^{\mathrm{f}}$ & $37.59 \pm 1.21^{\mathrm{f}}$ & $29.90 \pm 0.66^{\mathrm{f}}$ & $18.91 \pm 0.66^{\mathrm{f}}$ \\
\hline \multirow{2}{*}{ Plant } & 5 & $16.55 \pm 0.41^{\mathrm{a}}$ & $32.52 \pm 1.31^{\mathrm{a}}$ & $46.81 \pm 0.88^{\mathrm{a}}$ & $37.23 \pm 0.62^{\mathrm{a}}$ & $26.48 \pm 0.88^{\mathrm{a}}$ \\
growth & 6 & $15.99 \pm 0.09^{\mathrm{b}}$ & $29.28 \pm 0.70^{\mathrm{b}}$ & $44.28 \pm 0.32^{\mathrm{b}}$ & $34.80 \pm 0.32^{\mathrm{bc}}$ & $25.28 \pm 0.32^{\mathrm{b}}$ \\
regulator & 7 & $15.84 \pm 0.16^{\mathrm{bc}}$ & $28.41 \pm 0.49^{\mathrm{bc}}$ & $42.65 \pm 0.66^{\mathrm{c}}$ & $33.66 \pm 0.74^{\mathrm{cd}}$ & $24.18 \pm 0.38^{\mathrm{c}}$ \\
& 8 & $15.60 \pm 0.22^{\mathrm{c}}$ & $27.16 \pm 0.96^{\mathrm{cd}}$ & $39.99 \pm 0.22^{\mathrm{de}}$ & $32.52 \pm 1.05^{\mathrm{de}}$ & $19.87 \pm 0.69^{\mathrm{f}}$ \\
\hline
\end{tabular}

The net photosynthetic rate was higher in the "Yuhuangjin" treatment than in the water treatment in every growth period. The peak values were $46.81 \mu \mathrm{mol} \mathrm{m} \mathrm{m}^{-2} \mathrm{~s}^{-1}$ $\left(5\right.$ plants $\left.\mathrm{m}^{-2}\right), 44.28 \mu \mathrm{mol} \mathrm{m}^{-2} \mathrm{~s}^{-1}\left(6\right.$ plants $\left.\mathrm{m}^{-2}\right), 42.65 \mu \mathrm{mol} \mathrm{m}^{-2} \mathrm{~s}^{-1}\left(7\right.$ plants $\left.\mathrm{m}^{-2}\right)$ and $40.00 \mu \mathrm{mol} \mathrm{m} \mathrm{m}^{-2} \mathrm{~s}^{-1}\left(8\right.$ plants $\left.\mathrm{m}^{-2}\right)$ at the silking stage. The net photosynthetic rates in the "Yuhuangjin" treatments were higher than those in the water treatment by $8.15 \%$ (5 plants $\left.\mathrm{m}^{-2}\right), 9.55 \%\left(6\right.$ plants $\left.\mathrm{m}^{-2}\right), 9.95 \%\left(7\right.$ plants $\left.\mathrm{m}^{-2}\right)$ and $6.39 \%\left(8\right.$ plants $\left.\mathrm{m}^{-2}\right)$.

From the silking stage to the dough stage, the net photosynthetic rate declined by $43.42 \%$ (5 plants $\left.\mathrm{m}^{-2}\right), 42.90 \%$ (6 plants $\left.\mathrm{m}^{-2}\right), 43.29 \%\left(7\right.$ plants $\mathrm{m}^{-2}$ ) and $50.33 \%$ $\left(8\right.$ plants $\left.\mathrm{m}^{-2}\right)$. The net photosynthetic rate in the "Yuhuangjin" treatment was higher than that in the water treatment by $13.79 \%\left(5\right.$ plants $\left.\mathrm{m}^{-2}\right), 12.64 \%\left(6\right.$ plants $\left.\mathrm{m}^{-2}\right)$, $12.80 \%\left(7\right.$ plants $\left.\mathrm{m}^{-2}\right)$ and $5.08 \%\left(8\right.$ plants $\left.\mathrm{m}^{-2}\right)$ at the dough stage.

\section{Effects of plant growth regulator on chlorophyll fluorescence parameters of the leaves of northeast spring maize under different planting densities}

From the silking stage to the dough stage, the PSII maximum quantum yield showed a declining trend in the two treatments (Table 5). The $F v / F m$ declined by $3.16 \%$ $\left(5\right.$ plants $\left.\mathrm{m}^{-2}\right), 3.40 \%\left(6\right.$ plants $\left.\mathrm{m}^{-2}\right), 3.19 \%\left(7\right.$ plants $\left.\mathrm{m}^{-2}\right)$ and $3.41 \%\left(8\right.$ plants $\left.\mathrm{m}^{-2}\right)$ from the silking stage to the dough stage in the water treatment. The $F v / F m$ declined by $3.07 \%\left(5\right.$ plants $\left.\mathrm{m}^{-2}\right), 3.28 \%\left(6\right.$ plants $\left.\mathrm{m}^{-2}\right), 2.65 \%\left(7\right.$ plants $\mathrm{m}^{-2}$ ) and $2.17 \%$ (8 plants $\mathrm{m}^{-2}$ ) from the silking stage to the dough stage in the "Yuhuangjin" treatment. Compared 
with the water treatment, the PSII maximum quantum yield in the "Yuhuangjin" treatment decreased by a small amount. At the same time, the "Yuhuangjin" treatment increased the PSII maximum quantum yield.

With the increase in density, the $Y(I I)$ of the two treatments showed a decreasing trend (Table 6). From the silking stage to the dough stage, the $Y(I I)$ in the water treatment reduced by $7.04 \%$ ( 5 plants $\left.\mathrm{m}^{-2}\right), 47.64 \%\left(6\right.$ plants $\left.\mathrm{m}^{-2}\right), 47.40 \%\left(7\right.$ plants $\left.\mathrm{m}^{-2}\right)$ and $57.49 \%\left(8\right.$ plants $\left.\mathrm{m}^{-2}\right)$. The $Y(I I)$ in the "Yuhuangjin" treatment reduced by $42.44 \%$ $\left(5\right.$ plants $\left.\mathrm{m}^{-2}\right), 45.44 \%\left(6\right.$ plants $\left.\mathrm{m}^{-2}\right), 46.38 \%\left(7\right.$ plants $\left.\mathrm{m}^{-2}\right)$ and $53.42 \%\left(8\right.$ plants $\left.\mathrm{m}^{-2}\right)$ from the silking stage to the dough stage. The "Yuhuangjin" treatment reduced the decrease in $Y(I I)$ in the later stages of procreation. Compared with the water treatment, the $Y(I I)$ in the "Yuhuangjin" treatment increased at varying degrees. In the silking stage, the $Y(I I)$ values in the "Yuhuangjin" treatment were $0.71 \%\left(5\right.$ plants $\left.\mathrm{m}^{-2}\right), 1.32 \%$ $\left(6\right.$ plants $\left.\mathrm{m}^{-2}\right), 0.67 \%\left(7\right.$ plants $\left.\mathrm{m}^{-2}\right)$ and $3.80 \%\left(8\right.$ plants $\left.\mathrm{m}^{-2}\right)$ higher than those in the water treatment. In the dough stage, the $Y(I I)$ values in the "Yuhuangjin" treatment were 9.46\% (5 plants $\left.\mathrm{m}^{-2}\right), 5.58 \%\left(6\right.$ plants $\left.\mathrm{m}^{-2}\right), 2.61 \%\left(7\right.$ plants $\left.\mathrm{m}^{-2}\right)$ and $13.73 \%$ (8 plants $\mathrm{m}^{-2}$ ) higher than those in the water treatment.

Table 5. The effects of plant growth regulator on the Fv/Fm of spring maize leaves under different planting densities in Northeast China

\begin{tabular}{c|c|c|c|c}
\hline Treatment & $\begin{array}{c}\text { Density } \\
(\text { plants m }\end{array}$ & Silking & Grain filling stage & Dough stage \\
\hline & 5 & $0.799 \pm 0.002^{\mathrm{ab}}$ & $0.789 \pm 0.006^{\mathrm{abc}}$ & $0.774 \pm 0.009^{\mathrm{a}}$ \\
& 6 & $0.796 \pm 0.002^{\mathrm{ab}}$ & $0.787 \pm 0.005^{\mathrm{abc}}$ & $0.768 \pm 0.002^{\mathrm{a}}$ \\
Water & 7 & $0.791 \pm 0.010^{\mathrm{ab}}$ & $0.784 \pm 0.003^{\mathrm{abc}}$ & $0.766 \pm 0.011^{\mathrm{a}}$ \\
& 8 & $0.785 \pm 0.004^{\mathrm{b}}$ & $0.780 \pm 0.008^{\mathrm{c}}$ & $0.758 \pm 0.009^{\mathrm{a}}$ \\
\hline & 5 & $0.803 \pm 0.004^{\mathrm{a}}$ & $0.797 \pm 0.008^{\mathrm{a}}$ & $0.779 \pm 0.001^{\mathrm{a}}$ \\
Plant growth & 6 & $0.803 \pm 0.013^{\mathrm{a}}$ & $0.794 \pm 0.010^{\mathrm{ab}}$ & $0.779 \pm 0.019^{\mathrm{a}}$ \\
regulator & 7 & $0.793 \pm 0.004^{\mathrm{ab}}$ & $0.784 \pm 0.007^{\mathrm{abc}}$ & $0.772 \pm 0.013^{\mathrm{a}}$ \\
& 8 & $0.786 \pm 0.012^{\mathrm{b}}$ & $0.781 \pm 0.006^{\mathrm{bc}}$ & $0.770 \pm 0.013^{\mathrm{a}}$ \\
\hline
\end{tabular}

Table 6. The effects of plant growth regulator on the $Y(I I)$ of spring maize leaves under different planting densities in Northeast China

\begin{tabular}{c|c|c|c|c}
\hline Treatment & $\begin{array}{c}\text { Density } \\
(\text { plants m }\end{array}$ & Silking & Grain filling stage & Dough stage \\
\hline & 5 & $0.661 \pm 0.002^{\mathrm{ab}}$ & $0.608 \pm 0.024^{\mathrm{ab}}$ & $0.350 \pm 0.093^{\mathrm{ab}}$ \\
Water & 6 & $0.654 \pm 0.022^{\mathrm{ab}}$ & $0.593 \pm 0.024^{\mathrm{abc}}$ & $0.343 \pm 0.028^{\mathrm{ab}}$ \\
& 7 & $0.647 \pm 0.048^{\mathrm{ab}}$ & $0.576 \pm 0.030^{\mathrm{c}}$ & $0.340 \pm 0.049^{\mathrm{ab}}$ \\
& 8 & $0.615 \pm 0.039^{\mathrm{c}}$ & $0.532 \pm 0.050^{\mathrm{d}}$ & $0.261 \pm 0.047^{\mathrm{c}}$ \\
\hline & 5 & $0.666 \pm 0.005^{\mathrm{a}}$ & $0.614 \pm 0.016^{\mathrm{a}}$ & $0.383 \pm 0.048^{\mathrm{a}}$ \\
Plant growth & 6 & $0.663 \pm 0.007^{\mathrm{ab}}$ & $0.610 \pm 0.006^{\mathrm{ab}}$ & $0.362 \pm 0.040^{\mathrm{a}}$ \\
regulator & 7 & $0.652 \pm 0.024^{\mathrm{ab}}$ & $0.586 \pm 0.014^{\mathrm{bc}}$ & $0.350 \pm 0.054^{\mathrm{ab}}$ \\
& 8 & $0.638 \pm 0.008^{\mathrm{bc}}$ & $0.548 \pm 0.024^{\mathrm{d}}$ & $0.297 \pm 0.032^{\mathrm{bc}}$ \\
\hline
\end{tabular}

With the progress of procreation, the two $Y(N O)$ treatments generally showed upward trends (Table 7). In the same growth period, the $Y(N O)$ values of both treatments also increased with increasing density. Compared to the plant growth regulator treatment, the $Y(N O)$ in the water treatment increased by $21.01 \%$ (5 plants 
$\left.\mathrm{m}^{-2}\right), 24.26 \%\left(6\right.$ plants $\left.\mathrm{m}^{-2}\right), 34.38 \%\left(7\right.$ plants $\left.\mathrm{m}^{-2}\right)$ and $41.60 \%\left(8\right.$ plants $\left.\mathrm{m}^{-2}\right)$ from the silking stage to dough stage. The "Yuhuangjin" treatment increased the $Y(N O)$ by $19.63 \%\left(5\right.$ plants $\left.\mathrm{m}^{-2}\right), 18.78 \%\left(6\right.$ plants $\left.\mathrm{m}^{-2}\right), 21.03 \%\left(7\right.$ plants $\left.\mathrm{m}^{-2}\right)$ and $24.50 \%(8$ plants $\mathrm{m}^{-2}$ ) from the silking stage to the dough stage. The "Yuhuangjin" treatment reduced the $Y(N O)$ at varying degrees. In the silking stage, the water treatment reduced the $Y(N O)$ by $1.07 \%\left(5\right.$ plants $\left.\mathrm{m}^{-2}\right), 4.16 \%\left(6\right.$ plants $\left.\mathrm{m}^{-2}\right), 4.32 \%\left(7\right.$ plants $\left.\mathrm{m}^{-2}\right)$ and $5.14 \%\left(8\right.$ plants $\left.\mathrm{m}^{-2}\right)$ compared to the "Yuhuangjin" treatment. In the dough stage, the water treatment reduced the $Y(N O)$ by $2.20 \%\left(5\right.$ plants $\left.\mathrm{m}^{-2}\right), 8.39 \%\left(6\right.$ plants $\left.\mathrm{m}^{-2}\right)$, $13.83 \%\left(7\right.$ plants $\left.\mathrm{m}^{-2}\right)$ and $16.61 \%\left(8\right.$ plants $\left.\mathrm{m}^{-2}\right)$ compared to the "Yuhuangjin" treatment.

Table 7. The effects of plant growth regulator on the $Y(N O)$ of spring maize leaves under different planting densities in Northeast China

\begin{tabular}{|c|c|c|c|c|}
\hline Treatment & $\begin{array}{c}\text { Density } \\
\text { (plants } \mathbf{m}^{-2} \text { ) }\end{array}$ & Silking & Grain filling stage & Dough stage \\
\hline \multirow{4}{*}{ Water } & 5 & $0.319 \pm 0.004^{\mathrm{bc}}$ & $0.343 \pm 0.001^{\mathrm{c}}$ & $0.386 \pm 0.046^{c}$ \\
\hline & 6 & $0.334 \pm 0.022^{\mathrm{abc}}$ & $0.356 \pm 0.016^{\mathrm{c}}$ & $0.415 \pm 0.024^{\mathrm{bc}}$ \\
\hline & 7 & $0.357 \pm 0.008^{\mathrm{ab}}$ & $0.406 \pm 0.035^{\mathrm{ab}}$ & $0.479 \pm 0.006^{\mathrm{ab}}$ \\
\hline & 8 & $0.367 \pm 0.037^{\mathrm{a}}$ & $0.414 \pm 0.048^{\mathrm{a}}$ & $0.520 \pm 0.018^{\mathrm{a}}$ \\
\hline \multirow{4}{*}{$\begin{array}{l}\text { Plant growth } \\
\text { regulator }\end{array}$} & 5 & $0.322 \pm 0.010^{\mathrm{c}}$ & $0.339 \pm 0.006^{\mathrm{c}}$ & $0.378 \pm 0.002^{c}$ \\
\hline & 6 & $0.320 \pm 0.030^{\mathrm{bc}}$ & $0.349 \pm 0.009^{c}$ & $0.381 \pm 0.017^{\mathrm{c}}$ \\
\hline & 7 & $0.341 \pm 0.014^{\mathrm{abc}}$ & $0.366 \pm 0.019^{\mathrm{bc}}$ & $0.413 \pm 0.022^{\mathrm{bc}}$ \\
\hline & 8 & $0.348 \pm 0.004^{\mathrm{abc}}$ & $0.377 \pm 0.029^{\mathrm{abc}}$ & $0.434 \pm 0.019^{b}$ \\
\hline
\end{tabular}

With procreation, the $q N$ values of the two treatments generally showed upward trends at the different densities (Table 8). From the silking stage to the dough stage, the $q N$ value of the water treatment increased by $0.39 \%\left(5\right.$ plants $\left.\mathrm{m}^{-2}\right), 0.43 \%\left(6\right.$ plants $\left.\mathrm{m}^{-2}\right)$, $0.43 \%$ ( 7 plants $\mathrm{m}^{-2}$ ) and $0.44 \%\left(8\right.$ plants $\left.\mathrm{m}^{-2}\right)$. The $q N$ value of the "Yuhuangjin" treatment increased by $0.37 \%\left(5\right.$ plants $\left.\mathrm{m}^{-2}\right), 0.42 \%\left(6\right.$ plants $\left.\mathrm{m}^{-2}\right), 0.41 \%\left(7\right.$ plants $\left.\mathrm{m}^{-2}\right)$ and $0.44 \%\left(8\right.$ plants $\left.\mathrm{m}^{-2}\right)$ from the silking stage to the dough stage.

Table 8. The effects of plant growth regulator on $q N$ of spring maize leaves under different planting densities in Northeast China

\begin{tabular}{c|c|c|c|c}
\hline Treatment & $\begin{array}{c}\text { Density } \\
(\text { plants }\end{array} \mathbf{- n}^{-2}$ & Silking & Grain filling stage & Dough stage \\
\hline & 5 & $0.038 \pm 0.008^{\mathrm{d}}$ & $0.125 \pm 0.015^{\mathrm{abc}}$ & $0.424 \pm 0.008^{\mathrm{e}}$ \\
Water & 6 & $0.065 \pm 0.011^{\mathrm{c}}$ & $0.145 \pm 0.005^{\mathrm{ab}}$ & $0.490 \pm 0.008^{\mathrm{cd}}$ \\
& 7 & $0.102 \pm 0.011^{\mathrm{ab}}$ & $0.151 \pm 0.002^{\mathrm{ab}}$ & $0.532 \pm 0.025^{\mathrm{ab}}$ \\
& 8 & $0.113 \pm 0.010^{\mathrm{a}}$ & $0.156 \pm 0.005^{\mathrm{a}}$ & $0.554 \pm 0.027^{\mathrm{a}}$ \\
\hline & 5 & $0.023 \pm 0.009^{\mathrm{d}}$ & $0.108 \pm 0.008^{\mathrm{c}}$ & $0.395 \pm 0.044^{\mathrm{e}}$ \\
Plant growth & 6 & $0.059 \pm 0.004^{\mathrm{c}}$ & $0.120 \pm 0.020^{\mathrm{bc}}$ & $0.475 \pm 0.007^{\mathrm{d}}$ \\
regulator & 7 & $0.084 \pm 0.011^{\mathrm{b}}$ & $0.124 \pm 0.019^{\mathrm{bc}}$ & $0.496 \pm 0.010^{\mathrm{bcd}}$ \\
& 8 & $0.086 \pm 0.014^{\mathrm{a}}$ & $0.131 \pm 0.031^{\mathrm{a}}$ & $0.523 \pm 0.017^{\mathrm{a}}$ \\
\hline
\end{tabular}

The "Yuhuangjin" treatment reduced the increase of the $q N$ value and enhanced the photosynthetic performance of the leaves. With the increase in densities, the $q N$ values of the two treatments showed increasing trends. In terms of the plant growth regulator, 
the $q N$ values of the blades declined under the "Yuhuangjin" treatment. In the dough stage, compared with the water treatment, the "Yuhuangjin" treatment resulted in low $q N$ values of $6.83 \%\left(5\right.$ plants $\left.\mathrm{m}^{-2}\right), 3.20 \%\left(6\right.$ plants $\left.\mathrm{m}^{-2}\right), 6.75 \%\left(7\right.$ plants $\left.\mathrm{m}^{-2}\right)$ and $5.63 \%$ (8 plants $\left.\mathrm{m}^{-2}\right)$.

With the increase in densities, the $q P$ values of the two treatments gradually decreased after the silking stage (Table 9). The water treatment reduced the $q P$ values by $7.49 \%\left(5\right.$ plants $\left.\mathrm{m}^{-2}\right), 37.15 \%\left(6\right.$ plants $\left.\mathrm{m}^{-2}\right), 44.84 \%\left(7\right.$ plants $\left.\mathrm{m}^{-2}\right)$ and $57.25 \%$ $\left(8\right.$ plants $\mathrm{m}^{-2}$ ) from the silking stage to the dough stage. The "Yuhuangjin" treatment reduced the $q P$ values by $34.91 \%\left(5\right.$ plants $\left.\mathrm{m}^{-2}\right), 36.31 \%\left(6\right.$ plants $\left.\mathrm{m}^{-2}\right), 42.47 \%$ $\left(7\right.$ plants $\mathrm{m}^{-2}$ ) and $53.83 \%$ ( 8 plants $\mathrm{m}^{-2}$ ) from the silking stage to the dough stage. Compared with the water treatment, the "Yuhuangjin" treatment exhibited varying degrees of improvement. In the silking stage, the maximum $q P$ values were $2.05 \%$ $\left(5\right.$ plants $\left.\mathrm{m}^{-2}\right), 3.60 \%\left(6\right.$ plants $\left.\mathrm{m}^{-2}\right), 4.56 \%\left(7\right.$ plants $\left.\mathrm{m}^{-2}\right)$ and $4.94 \%\left(8\right.$ plants $\left.\mathrm{m}^{-2}\right)$ higher than those in the water treatment.

\section{Effects of plant growth regulator on yield of spring maize in different planting densities in northeast China}

With the increase in densities, the water treatment first exhibited an increasing then decreasing trend in the yield (Table 10). The highest yield was measured in the 7 plants $\mathrm{m}^{-2}$ density $\left(12346.40 \mathrm{~kg} \mathrm{ha}^{-1}\right)$, which was $34.94 \%, 12.89 \%$ and $9.58 \%$ higher than the yields in the 5 plants $\mathrm{m}^{-2}, 6$ plants $\mathrm{m}^{-2}$ and 8 plants $\mathrm{m}^{-2}$ densities, and these differences were significant.

Table 9. The effects of plant growth regulator on qP of spring maize leaves under different planting densities in Northeast China

\begin{tabular}{c|c|c|c|c}
\hline Treatment & $\begin{array}{c}\text { Density } \\
\left(\text { plants }^{-2}\right)\end{array}$ & Silking & Grain filling stage & Dough stage \\
\hline & 5 & $0.839 \pm 0.039^{\mathrm{abc}}$ & $0.754 \pm 0.006^{\mathrm{a}}$ & $0.524 \pm 0.076^{\mathrm{ab}}$ \\
Water & 6 & $0.814 \pm 0.015^{\mathrm{abc}}$ & $0.734 \pm 0.036^{\mathrm{a}}$ & $0.512 \pm 0.042^{\mathrm{ab}}$ \\
& 7 & $0.798 \pm 0.019^{\mathrm{bcd}}$ & $0.711 \pm 0.045^{\mathrm{a}}$ & $0.440 \pm 0.031^{\mathrm{bc}}$ \\
& 8 & $0.755 \pm 0.049^{\mathrm{d}}$ & $0.647 \pm 0.080^{\mathrm{b}}$ & $0.322 \pm 0.025^{\mathrm{d}}$ \\
\hline \multirow{3}{*}{ Plant growth } & 5 & $0.856 \pm 0.002^{\mathrm{a}}$ & $0.763 \pm 0.010^{\mathrm{a}}$ & $0.557 \pm 0.099^{\mathrm{a}}$ \\
regulator & 6 & $0.843 \pm 0.024^{\mathrm{ab}}$ & $0.758 \pm 0.005^{\mathrm{a}}$ & $0.537 \pm 0.038^{\mathrm{ab}}$ \\
& 7 & $0.835 \pm 0.010^{\mathrm{abc}}$ & $0.720 \pm 0.029^{\mathrm{a}}$ & $0.480 \pm 0.065^{\mathrm{ab}}$ \\
& 8 & $0.792 \pm 0.012^{\mathrm{cd}}$ & $0.661 \pm 0.046^{\mathrm{b}}$ & $0.366 \pm 0.046^{\mathrm{cd}}$ \\
\hline
\end{tabular}

Table 10. The effects of plant growth regulator on yield factors of spring maize under different planting densities in Northeast China

\begin{tabular}{c|c|c|c|c|c}
\hline Treatment & $\begin{array}{c}\text { Density } \\
\left(\text { plants m }^{-2}\right)\end{array}$ & $\begin{array}{c}\text { Rows } \\
\text { per ear }\end{array}$ & Kernels row & $\begin{array}{c}\text { Hundred grain weight } \\
(\mathbf{g})\end{array}$ & $\begin{array}{c}\text { Yield } \\
\left(\mathbf{k g ~ h a}^{-\mathbf{1}}\right)\end{array}$ \\
\hline & 5 & $16.05^{\mathrm{a}}$ & $33.95^{\mathrm{bc}}$ & $33.97^{\mathrm{a}}$ & $7868.41^{\mathrm{d}}$ \\
Water & 6 & $15.93^{\mathrm{a}}$ & $35.58^{\mathrm{abc}}$ & $32.31^{\mathrm{a}}$ & $9404.50^{\mathrm{c}}$ \\
& 7 & $16.39^{\mathrm{a}}$ & $33.89^{\mathrm{bc}}$ & $32.74^{\mathrm{a}}$ & $10618.44^{\mathrm{ab}}$ \\
& 8 & $16.00^{\mathrm{a}}$ & $31.50^{\mathrm{de}}$ & $29.47^{\mathrm{b}}$ & $9689.59^{\mathrm{bc}}$ \\
\hline & 5 & $15.80^{\mathrm{a}}$ & $35.95^{\mathrm{ab}}$ & $34.49^{\mathrm{a}}$ & $7887.15^{\mathrm{d}}$ \\
Plant growth & 6 & $15.95^{\mathrm{a}}$ & $33.50^{\mathrm{cd}}$ & $34.36^{\mathrm{a}}$ & $9450.90^{\mathrm{c}}$ \\
regulator & 7 & $15.45^{\mathrm{a}}$ & $36.50^{\mathrm{a}}$ & $34.61^{\mathrm{a}}$ & $11428.18^{\mathrm{a}}$ \\
& 8 & $15.90^{\mathrm{a}}$ & $31.28^{\mathrm{e}}$ & $31.71^{\mathrm{ab}}$ & $10435.83^{\mathrm{abc}}$ \\
\hline
\end{tabular}


Compared with the water treatment, the production in the "Yuhuangjin" treatment increased, and the highest yield was measured in the 7 plants $\mathrm{m}^{-2}$ density $(13290.95 \mathrm{~kg}$ $\left.\mathrm{ha}^{-1}\right)$, but this difference was not significant. Compared with the water treatment, the yields in the "Yuhuangjin" treatment increased by $6.14 \%\left(5\right.$ plants $\left.\mathrm{m}^{-2}\right), 0.48 \%$ (6 plants $\left.\mathrm{m}^{-2}\right), 7.65 \%\left(7\right.$ plants $\left.\mathrm{m}^{-2}\right)$ and $3.81 \%\left(8\right.$ plants $\left.\mathrm{m}^{-2}\right)$. With the increase in density, rows per ear, kernels row and hundred-grain weight did not obviously change, and the differences were not significant. For the "Yuhuangjin" treatment, the differences between row and kernel numbers of the different densities were not significant, while the hundred-grain weight increased, but not significantly.

\section{Discussion}

The main factors of maize yields include effective ear number, spike number and grain weight per unit area. The effective ear number of the group is easiest to control and is one of the main ways to increase maize yields. With the increase in density, the yield first increased and then decreased, the ear rows and the line grain number decreased, and kilo-grain weight decreased (Gilberto et al., 2013; Li et al., 2014; Niyogi, 2017). In this experiment, the changes in the yields at different densities in the two treatments are consistent with the results of previous studies. The maximum yields in both treatments occurred at the 7 plants $\mathrm{m}^{-2}$ density. The maximum yields were $10618.44 \mathrm{~kg} \mathrm{ha}^{-1}$ (water treatment) and $11428.18 \mathrm{~kg} \mathrm{ha}^{-1}$ ("Yuhuangjin" treatment). Compared with the water treatment, the "Yuhuangjin" treatment increased the yields by $0.24 \%$ (5 plants $\left.\mathrm{m}^{-2}\right), 0.49 \%\left(6\right.$ plants $\left.\mathrm{m}^{-2}\right), 7.63 \%\left(7\right.$ plants $\left.\mathrm{m}^{-2}\right)$ and $7.70 \%(8$ plants $\left.\mathrm{m}^{-2}\right)$. The differences in the ear rows and the line grain number were not obvious. The experiment also showed that the "Yuhuangjin" treatment mainly increased the hundred-grain weight, which influenced the yield.

The formation of maize yield is a group production process and not simple individual accumulation. The production of a maize population is related to the $L A I$, canopy characteristics, photosynthetic productivity and assimilation products of the entire population (Khoshbakht et al., 2017). During the growth period, the LAI exhibited a curve with a single peak, and the peak $L A I$ was reached in the silking stage. With the increase in density, the maize yield mainly depends on the photosynthetic characteristics of the leaf groups, especially the photosynthetic capacity of the upper part and the duration of high light. In this experiment, the change in the LAI with density was consistent with the results obtained by Bian (Bian et al., 2011) and the spraying of "Yuhuangjin" reduced the LAI. The LAI values in the "Yuhuangjin" treatment were $0.89 \%$ (5 plants $\left.\mathrm{m}^{-2}\right), 3.95 \%\left(6\right.$ plants $\left.\mathrm{m}^{-2}\right), 1.23 \%\left(7\right.$ plants $\left.\mathrm{m}^{-2}\right)$ and $8.74 \%(8$ plants $\mathrm{m}^{-2}$ ) lower than those in the water treatment. Spraying "Yuhuangjin" can reduce the leaf area of the colony, and it can also reduce the mutual shading between individuals within a group and improve the permeability of the group. The positive effects of the "Yuhuangjin" treatment are greater than the losses caused by the decreases in the leaf area. From the silking stage to the dough stage, LAI decreased by $3.75 \%$ ( 5 plants $\left.\mathrm{m}^{-2}\right), 6.47 \%\left(6\right.$ plants $\left.\mathrm{m}^{-2}\right), 7.14 \%\left(7\right.$ plants $\left.\mathrm{m}^{-2}\right)$ and $14.60 \%\left(8\right.$ plants $\left.\mathrm{m}^{-2}\right)$ compared to the water treatment. The aging process slows in the later stages. With the increase in density, the $L A I$ of the group also increased. Increased densities also increased the supply levels of the source. The pre-control effect of "Yuhuangjin" on the leaf area of the group increased the permeability of the group and delayed the aging process of the leaf blades. 
Chlorophyll is an important material in the photosynthesis process. Chlorophyll is involved in the absorption of light energy by a plant and the conversion process. The change in chlorophyll content can be reflected in the blades during the aging process. The chlorophyll content can also reflect the photosynthetic performance and is closely linked to the yield formation (Ma and Dwyer, 1998). Increasing the planting density can decrease the chlorophyll contents of individual plant leaves in a group, and it can reduce the production capacity of single plants. The "Yuhuangjin" treatment increased the chlorophyll content of the leaves and increased the photosynthetic capacity of the leaves. The living environment of an individual plant worsens with the increase in the number of maize plants number per unit area. These density increases will result in the decrease of the net photosynthetic rate of the group. The results of the "Yuhuangjin" treatment in this experiment show that the net photosynthetic rate of the blades is improved by using "Yuhuangjin". The function time of the blade is extended, which created the conditions necessary for higher yields.

The light energy absorbed by the photosynthetic apparatus is mainly utilized in the following ways: to promote photochemical reactions, to dissipate in the form of heat energy and to emit in the form of fluorescence. These three paths are interrelated with each other. The fluorescence signals emitted by plant bodies contain rich photosynthetic information that can be used to predict crop yield potentials (Gong et al., 2006). With the increase of densities, the relative chlorophyll content (SPAD) will decrease, and plant growth regulators can improve the chlorophyll content of maize leaves (Li et al., 2011). This study shows that the SPAD value of the plants treated by "Yuhuangjin" increased at different degrees under different densities. The SPAD values in the "Yuhuangjin" treatment were 7.14\% (5 plants $\left.\mathrm{m}^{-2}\right), 9.19 \%$ (6 plants $\left.\mathrm{m}^{-2}\right), 7.85 \%$ $\left(7\right.$ plants $\left.\mathrm{m}^{-2}\right)$ and $8.77 \%$ ( 8 plants $\mathrm{m}^{-2}$ ) higher than those in the water treatment. By regulating the canopy structure of the group, "Yuhuangjin" reduced the shading of the plants and increased the light energy intercepted by the ear leaves. These conditions laid the foundation for the synthesis of chlorophyll. With the increase in density, the filling stage was reflected in the PSII center of the ear, while the $q P$ and $q N$ increased. A suitable planting density can help improve the apparent quantum efficiency of maize leaves, and it can increase the primary photochemical efficiency, PSII quantum yield, and photochemical quenching coefficient. A suitable planting density can also reduce the photochemical quenching coefficients of the blades (Yang et al., 2009). The chlorophyll fluorescence parameters of the "rod and three leaves" under the two strains showed a unique phenomenon. The "Yuhuangjin" treatment increased the photosynthetic capacity, and the actual quantum yield increased significantly (Xu et al., $2008)$. With the increase in densities, the $F v / F m, Y(I I)$ and $q P$ decreased, while the $Y(N O)$ and $q N$ increased in the water treatment. This result suggested that increasing planting density can lead to worse population canopy conditions and can lower the fluorescence yield. Spraying "Yuhuangjin" increased the $F v / F m, Y(I I)$ and $q P$, while it decreased the $Y(N O)$ and $q N$. The "Yuhuangjin" treatment improved the maximum quantum yield, improved the ability of the leaves to adapt to strong light, reduced the chemical quenching parameters, enhanced the leaf physiological functions and improved the utilization of energy and the actual quantum yield of the blade. Compared with the water treatment, the "Yuhuangjin" treatment resulted in smaller decreases in $F v / F m, Y(I I)$ and $q P$, higher reductions in $Y(N O)$, and reductions in the $q N$. Spraying "Yuhuangjin" delayed the senescence of the leaves and increased the duration of high photosynthetic efficiency, which laid the foundation for higher yields. The changes in 
the net photosynthetic rate and chlorophyll fluorescence parameters of the leaf blades showed a unique phenomenon. Increasing the planting density can reduce the photosynthetic capacity of individual plants in the population. Spraying "Yuhuangjin" can improve the photosynthetic capacity of individual plants.

\section{Conclusion}

In the water treatment, the $L A I$ increased, and the $S P A D$ value of the group decreased with the increase in density. The group yield first increased and then decreased. The maximum yield was $10618.44 \mathrm{~kg} \mathrm{ha}^{-1}\left(7\right.$ plants $\left.\mathrm{m}^{-2}\right)$. The $P n$ decreased, and the chlorophyll fluorescence parameters $F v / F m, Y(I I)$ and $q P$ decreased, while $Y(N O)$ and $q N$ increased. In the "Yuhuangjin" treatment, the $L A I$ declined, the SPAD increased, the $P n$ increased, the chlorophyll fluorescence parameters $F v / F m, Y(I I)$ and $q P$ increased, and the $Y(N O)$ and $q N$ decreased. The maximum yield was $11428.18 \mathrm{~kg} \mathrm{ha}^{-1}$ $\left(7\right.$ plants $\left.\mathrm{m}^{-2}\right)$. The "Yuhuangjin" treatment slowed the aging process of the leaves, improved the photosynthetic capacity of the leaves and increased production. In maize production, it is important to pay more attention on obtain high yields by increasing the planting density in Heilongjiang Province. We still have a lot of work to do to reveal the effects of plant density and plant growth regulators on the physiological and molecular levels of maize.

Acknowledgements. This work was supported by Heilongjiang Provincial Funding for National Key R\&D Programs of China (GX18B029), National Key R\&D Program of China (2017YFD0300506, 2016YFD0300103) and "Academic Backbone" Project of Northeast Agricultural University (17XG23). We thank the anonymous reviewers and the editor for their valuable comments and suggestions, which distinctly contributed to the improvement of this paper.

Conflict of Interests. Authors state no conflict of interests.

\section{REFERENCES}

[1] Benari, T., Makowski, D. (2006): Analysis of the trade-off between high crop yield and low yield instability at the global scale. - Environmental Research Letters 11(10): 104005.

[2] Bian, D. H., Zhang, R. D., Duan, L. S., Li, J. M., Li, Z. H. (2011): Effects of partial spraying of plant growth regulator on canopy structure, chlorophyll fluorescence characteristic and yield of summer maize (Zea mays L.). - Acta Agriculture BorealiSinica 26(3): 139-145.

[3] Biswas, D. K., Ma, B. L. (2017): Effect of nitrogen rate and fertilizer nitroge source on physiology, yield, grain quality, and nitrogen use efficiency in corn. - Canadian Journal of Plant Science 96(3): 392-403.

[4] Chen, G. P., Yang, G. H., Zhao, M., Wang, L. C., Wang, Y. D., Xue, J. Q., Gao, J. L., Li, D. H., Dong, S. T., Li, C. H., Song, H. X., Zhao, J. R. (2008): Studies on maize small area super-high yield trails and cultivation technique. - Journal of Maize Sciences 16(4): 1-4.

[5] Cheng, S., Liu, N. (2017): Study on the effects of ethephon paclobutrazol and indoloacetic acid on the growth physiology and yield components of maize. Agricultural Technology \& Equipment 335(11): 17-18,21.

[6] Cicchino, M., Edreira, J., Otegui, M. (2013): Maize physiological responses to heat stress and hormonal plant growth regulators related to ethylene metabolism. - Crop Science 53(5): 2135-2146. 
[7] Diallo, L., Cao, Q., Yang, F., Yang, Z., Cui, J., Gang, L., Dafaalla, T. I. M., Diarso, M., Ahmad, W. (2015): Seed priming effects of Yuhuangjin on spring maize. - Journal of Animal \& Plant Sciences 25(3): 747-754.

[8] Dong, C. Y., Yang, X. G., Yang, J., Xie, W. J., Ye, Q., Zhao, J., Li, K. N. (2013): The temporal variation characteristics and spatial distribution laws of drought of spring maize in northern China. - Scientia Agricultura Sinica 46(20): 4234-4245.

[9] Fan, H. C., Gu, W. R., Wei, J. P., Wang, Y. L., Meng, Y., Zhang, L. G., Li, J., Wei, S. (2017): Mechanism of lodging resistance of maize improved by plant growth regulator. Jiangsu Journal of Agricultural Sciences 33(2): 253-262.

[10] Farhad, S., Mehdi, R. (2015): Effect of different levels of drip irrigation, plant density and spacing on the yield of maize hybrid (KSC700). - Maydica 60(2): 19-26.

[11] Gilberto, O., Koteyeva, N. K., Voznesenskaya, E. V., Edwards, G. E., Sage, T. L., Rowan, S. F., Columbus, J. T. (2013): Evolution of leaf anatomy and photosynthetic pathways in portulacceae. - American Journal of Botany 100(12): 2388-2402.

[12] Gong, Q. Z., Lv, J. Y., Xu, B. C., Li, F. M., Zhang, H. B. (2006): Effect of water stress on chlorophyll fluorescence paramenters and WUE of wheat under different planting models. - Journal of Northwest Science-Technology University of Agriculture and Forestry (Natural Science Edition) 34(5): 83-92.

[13] Hwang, J. S., Choo, Y. S. (2016): Solute patterns and diurnal variation of photosynthesis and chlorophyll fluorescence in Korean coastal sand dune plants. - Photosynthetica 55(1): 1-14.

[14] Inamoto, K., Nagasuga, K., Yano, T., Yamazaki, H. (2015): Influence of light intensity on the rate of photosynthesis and dry matter accumulation in Oriental hybrid lily 'Siberia' at different developmental stages. - Journal of Pomology \& Horticultural Science 90(3): 259-266.

[15] Kang, M. Z., Yang, L. L., Zhang, B. G., Reffye, P. D. (2011): Correlation between dynamic tomato fruit-set and source-sink ratio: a common relationship for different plant densities and seasons. - Annals of Botany 107(5): 805-815.

[16] Khoshbakht, D., Asghari, M. R., Haghighi, M. (2017): Influence of foliar application of polyamines on growth, gas exchange characteristics, and chlorophyll fluorescence in Bakraii citrus under saline conditions. - Photosynthetica 56(2): 731-742.

[17] Li, C. H., Zhao,Y. L., Yang, G. H., Luan, L. M., Wang, Q., Li, N. (2007): Effects of shading on photosynthetic characteristics of different genotype maize. - Chinese Journal of Applied Ecology 18(6): 1259-1264.

[18] Li, X. Y., Tang, Q. Y., Li, D. Q., Li, W. K., Li, H. L., Cai, Q. H. (2011): Effects of different plant densities on the photosynthetic-physiological characters and yield traits in spring maize grown on super-high yielding paddy field. - Acta Agriculturae BorealiSinica 26(5): 174-180.

[19] Li, J. H., Du, Y. Y., Yang, J., Huo, L. Y., Zhao, H. W. (2014): Effects of density and chemical control agent on agronomic traits and yield of compact corn Fengyu 4. - Seed 33(3): 89-93.

[20] Li, Y., Liu, H. J., Huang, G. H. (2016): The effect of nitrogen rates on yields and nitrogen use efficiencies during four years of wheat-maize rotation cropping seasons. - Agronomy Journal 108(5): 2076-2088.

[21] Li, S. K., Zhao, J. R., Dong, S. T., Zhao, M., Li, C. H., Cui, Y. H., Liu, Y. H., Gao, J. L., Xue, J. Q., Wang, L. C., Wang, P., Lu, W. P., Wang, J. H., Yang, Q. F., Wang, Z. M. (2017): Advances and prospects of maize cultivation in China. - Scientia Agricultura Sinica 50(11): 1941-1959.

[22] Liao, R. W., Liu, J. M., Bai, Y. M., An, S. Q., Liang, H., Lu, J. L., Le, Z. Y., Cao, Y. J. (2014): Spatial distribution and temporal variation of maize root in the soil under field conditions. - Chinese Journal of Eco-Agriculture 22(3): 284-291.

[23] Ma, B. L., Dwyer, L. M. (1998): Nitrogen uptake and use of two contrasting maize hybrids in leaf senescence. - Plant Soil 199(2): 283-291. 
[24] Meng, X. M., Sun, N., Bian, S. F., Fang, X. Q., Zhao, H. X., Zhang, L. H., Tan, G. B., Yan, W. P. (2016): Effects of plant growth regulator on the stem agronomic characters and yield of spring maize. - Journal of Northeast Agricultural Sciences 41(6): 16-20.

[25] Niyogi, K. K. (2017): Editorial overview: Physiology and metabolism: Light responses from chemoreceptor to photosynthesis and photoprotection. - Current Opinion in Plant Biology 37: 4-5.

[26] Ren, B. Z., Fan, X., Dong, S. T., Liu, P., Zhao, B., Zhang, J. W. (2017a): Effect of plant density and nitrogen rate on yield, nitrogen uptake and use efficiency of summer maize hybrids with different plant height. - Journal of Plant Nutrition and Fertilizer 23(2): 269277.

[27] Ren, B. Z., Liu, W., Zhang, J. W., Dong, S. T., Liu, P., Zhao, B. (2017b): Effects of plant density on the photosynthetic and chloroplast characteristics of maize under high-yielding conditions. - The Science of Nature 104(3-4): 12.

[28] Roy, A. K., Claudia, W. R., Deen, B., Lauzon, J., Bruulsema, T. (2014): Nitrogen application rate, timing and history effects on nitrous oxide emissions from corn (Zea mays L.). - Canadian Journal Soil Science 94(4): 563-573.

[29] Rutger, J. N., Crowder, L. V. (1967): Effect of population and row width on corn silage yields. - Agronomy Journal 59(5): 475-576.

[30] Sangakkara, R., Bandaranayake, S., Attanayake, U., Stamp, P. (2012): Impact of associated inter crops on growth and yield of maize (Zea mays L.) in major seasons of south Asia. - Maydica 57(1): 6-10.

[31] Xu, J. M., Gao, H. Q., Mao, S. G., Wang, X., Li, C. S., Ji, Y. Q., Lu, W. P. (2008): Effects of wide row space double plant cultivation on the characteristic of photosynthesis at later growth stage in maize (Zea Mays L). - Journal of Yangzhou University (Agricultural and Life Science Edition) 29(1): 66-70.

[32] Yan, Y. D., Jiang, Z. B., Xu, F. L., Wang, Y. K., Zou, C. (2009): Analysis of the soil texture and fertility status of hillside close-planting jujube field on the loess plateau. Agricultural Research in the Arid Areas 27(3): 174-178.

[33] Yang, Y. W., Wu, X. D. (2009): Effect of the different planting densities on the photosynthetic characteristics chlorophyll fluorescence parameters and yield of waxy Maize. - Journal of Anhui Agricultural Sciences 37(18): 8403-8405.

[34] Zhang, Q., Zhang, L. Z., Jochem, E., Werf, W. V. D., Zhang, W. Q., Duan, L. S. (2014): Maize yield and quality in response to plant density and application of a novel plant growth regulator. - Field Crop Research 164(1): 82-89.

[35] Zhang, P., Wei, T., Cai, T., Ali, S., Han, Q. F., Ren, X. L., Jia, Z. K. (2017): Plastic-film mulching for enhanced water-use efficiency and economic returns from maize fields in semiarid China. - Frontiers in Plant Science 8. doi: 10.3389/fpls.2017.00512.

[36] Zhao, M., Li, J. G., Zhang, B., Dong, Z. Q., Wang, M. Y. (2006): Compensation mechanism of high yield and potential tapping of crops. - Acta Agronomica Sinica 32(10): 1566-1572. 